単回摂取後のエチゾラムおよび主要代謝物の尿中排泄プロファイル

和田美暁，志摩典明，鎌田 徹，松田駿太朗，石川亜香里，新田篤志， 浅井龍太郎，掛橋秀直，藤井史保子，佐々木啓子，鎌田寛恵，片木宗弘

大阪府警察本部刑事部科学捜査研究所

干541-0053 大阪市中央区本町 1-3-18

\title{
Urinary excretion profiles of etizolam and its main metabolites after a single oral dose
}

\author{
Misato Wada, Noriaki Shima, Tooru Kamata, Shuntaro Matsuta, Akari Ishikawa, \\ Atsushi Nitta, Ryutaro Asai, Hidenao Kakehashi, Shihoko Fujii, Keiko Sasaki, \\ Hiroe Kamata and Munehiro Katagi
}

Forensic Science Laboratory, Osaka Prefectural Police Head Quarters

1-3-18, Hommachi, Chuo-ku, Osaka 541-0053, Japan

(Received 30 October 2020; accepted 3 December 2020;

Published online 20 January 2021 in J-STAGE DOI: 10.3408/jafst.801)

In this study, the excretion profiles of etizolam (EZ) and its main metabolites including conjugates in urine have been investigated to obtain fundamental information for proving the drug intake in the cases of drug-related crimes. Urine specimens were collected from three volunteers during about $200 \mathrm{~h}$ after a single oral ingestion of EZ (1 mg). Three glucuronides (including diastereomers) of 8- $\alpha$-hydroxyetizolam (EZ-M3) and 1-hydroxyetizolam (EZ-M6) along with free EZ-M3 and EZ-M6 were detected for the first time directly as metabolites of EZ using liquid chromatography-tandem mass spectrometry with a C18 semi-micro column. EZ, EZ-M3 and EZ-M6 were quantified using the authentic standards, and urinary concentrations of the glucuronides were calculated based on the increased amounts of EZ-M3 and EZ-M6 after enzymatic hydrolysis. The quantitative results demonstrated that the ratios of amounts of EZ-M3 and EZ-M6 including their glucuronides excreted in urine to the dose ranged about $18-22 \%$ and $9.5-14 \%$, respectively, although that of the unchanged EZ was less than $0.3 \%$. The glucuronide of EZ-M6 reached the highest concentration (more than $200 \mathrm{ng} / \mathrm{mL}$ ) of metabolites in the early period (within $12 \mathrm{~h}$ ) after intake. However, in a latter period ( $24 \mathrm{~h}$ or later) after intake, the concentration of EZ-M3 or its glucuronides was higher than that of glucuronide of EZ-M6 in most of the samples. The conjugation percentages of EZ-M3 and EZM6 were calculated to be approximately $50 \%$ and $98 \%$ or higher, respectively. This study suggested that the detectable duration of EZ-M3 (approximately one week 
after intake, Limit of detection: $0.05 \mathrm{ng} / \mathrm{mL}$ ) is longer than those of EZ and EZM6. In addition, the enzymatic hydrolysis prior to analysis is expected to prolong the detectable duration of EZ-M3 slightly.

\section{Key words: Etizolam, Metabolite, Urinary excretion profile, LC-MS/MS, Hyp- notics}

\section{緒 言}

日本国内で処方される催眠作用を有する医薬品 は, ベンゾジアゼピン系(フルニトラゼパムなど), 非ベンゾジアゼピン系（ゾルピデムなど），バルビ ツール酸系（フェノバルビタールなど），オレキシ ン受容体拮抗系（スボレキサントなど）抢よびメラ トニン受容体作動系（ラメルテオン）に大別され， 概ね30～40種類の薬物が流通している．これらの薬 物は処方箋医薬品ではあるものの比較的入手が容易 であるため，その催眠作用を利用して，性犯罪や殺 人などの凶悪犯罪に悪用されることが多い.

エチゾラム $(\mathrm{EZ})$ は, 吉富製薬 (現·田辺三菱 製薬）によって1983年に開発・承認された，チエ） トリアゾロジアゼピン系（広くはベンゾジアゼピン 系）に属する薬物で, 鎮静・催眠作用と共に, 抗不 安, 抗うつ, 筋緊張弛緩作用を有し, 幅広い疾患に 適応がある。一方，その臨床での適応に付随して， 乱用性が危惧されており，向精神薬として規制する 必要性が議論されてきた。 国際機関である薬物依存 専門委員会 (Expert Committee on Drugs Dependence, ECDD）抢よび国際麻薬統制委員会（International Narcotics Control Board, INCB) は EZ の 乱用性を中等度と評しているものの ${ }^{1)}$, 流通してい る国（日本，イタリア，インドなど）が少ないこと もあって, 近年まで Psychotropic Substances（向精 神薬）としての規制はなかったが，2019年に ECDDによって Psychotropic Substances (Schedule N）として規制すべきとの通告および勧告がな された2). 一方, 日本に打ける EZ の流通量は発売 当初から多く, 2010年の統計では, ベンゾジアゼピ ン系抢よび非ベンゾジアゼピン系を含む乱用症例の なかで第三位の症例数になって抢り ${ }^{3,4)}$, 乱用リス クの高い薬剤として認められ，国際機関に先立ち
2016年から麻薬および向精神薬取締法の第三種向精 神薬として規制されている5).

このような歴史を有する EZは，自己による乱用 だけでなく，性犯罪や殺人に関連して悪用される ケースも多く, 法薬毒物分野において重要な薬物で ある。通常，催眠作用を示す薬物が性犯罪などに悪 用されたケースにおいて，その使用の証明には被害 者の尿試料が第一選択として鑑定に供される．薬物 の尿中排泄プロファイルは，尿鑑定を実施する際の 基礎データとして必須であり，そのデータに基づい て，分析ターゲットとして最適な成分（未変化体あ るいは代謝物）の選定やその検出可能期間の推定を 行うほか, 成分の検出 /不検出が被害日時からの経 過時間と整合性があるかなど，供述や事件の信憑性 を判断するうえでも重要である。これまでに，流通 量の多い他の睡眠薬（フルニトラゼパム抢よびトリ アゾラムなど）では，ヒトについての代謝物を含め た尿中排泄プロファイルが報告されており ${ }^{6-10)}$ ，検 出可能期間などについての情報を取得することが可 能である.しかしながら，EZについては，国際的 な流通が少ないこともあって，ヒトに抢ける尿中排 泄プロファイルに関する報告はなく，1978年に Katoらによってラットを対象にした尿および糞便 排泄が報告されているのみである11)。当該データは 人における知見ではないため種差を考慮する必要が あるうえに, 当時の分析装置では低濃度領域 (sub$\mathrm{ng} / \mathrm{mL}$ ）の推移や第二相代謝物（抱合代謝物）を 十分に検討するには限界があった。

そこで本研究では，EZを単回摂取した被験者 3 名について，液体クロマトグラフィー／タンデム質 量分析（LC-MS/MS）を用いて尿中から未变化体 および主要代謝物（第一相抢よび第二相代謝物）を 高感度に検出すると共に，摂取証明を行う上で重要 なデータとなるそれらの尿中排泄プロファイルを検 
討し，分析ターゲットとして最適な成分や摂取証明 が可能な期間について考察した。

\section{材料および方法}

\section{1. 実験材料}

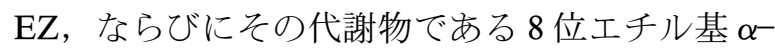
水酸化体（EZ-M3）打よび 1 位メチル基水酸化体 （EZ-M6）は，吉富製薬（現・田辺三菱製薬）から 提供を受けた。 エチゾラム $-d 3(\mathrm{EZ}-d 3$, 内部標準 物質）のメタノール溶液 $(100 \mu \mathrm{g} / \mathrm{mL})$ 抢よび $\beta-$ グルクロニダーゼ Type $\mathrm{X}-\mathrm{A}$ （from E. coli，グル クロニダーゼ活性 : 1,660 units/mg protein) はいず れも Sigma-Aldrich 製を使用した。 EZ，EZ-M3 お よび EZ-M6は， $1 \mathrm{mg} / \mathrm{mL}$ のメタノール溶液を標 準溶液として調製後冷凍保存し, $\mathrm{EZ}-d 3$ と共に使 用直前に適宜超純水あるいはブランク尿で希釈して 用いた。ブランク尿は富士フイルム和光純薬製アジ ア人ヒト尿を使用した。移動相の調製に使用した 1 $\mathrm{mol} / \mathrm{L}$ 酢酸アンモニウム溶液（高速液体クロマト グラフ用）およびメタノール（LC/MS 用），なら びにその他の有機溶媒（特級）はいずれも富士フイ ルム和光純薬から購入した.

\section{2. $\mathbf{E Z ~}$ 摂取者からの採尿}

本研究は, 日本法科学技術学会倫理審査委員会の 審査と承認（承認番号：31M5）を受けた手順に基 づき行った。なお，本研究で対象となった被験者に おいては，本研究に参加する 1 ケ月前まで遡り,

EZ を摂取していないことを確認している.

本研究では，デパス錠 $1 \mathrm{mg}$ (EZとして $1 \mathrm{mg}$ を含有）を単回経口摂取した被験者 3 名（Subjects 1-3：30代男性，40代男性，40代男性）から，摂取 直前, および摂取後最長 215 時間にわたって概ね 4 $\sim 8$ 時間毎に，尿試料（尿量を記録したうえで約 10 $\mathrm{mL}$ ) の提供を受けた。尿試料は分析までー $20{ }^{\circ} \mathrm{C} て ゙$ 保存した.

\section{3. 前処理 (試料調製)}

\section{1 除タンパク処理（定性分析および抱合体分析}

\section{用）}

尿 $100 \mu \mathrm{L}$ にメタノールを 3 倍量 $(300 \mu \mathrm{L})$ 加え て擋找後, 遠心 $\left(9,000 \mathrm{rpm}, 5 \mathrm{~min}, 4{ }^{\circ} \mathrm{C}\right)$ して除 タンパク処理を行った。遠心後，上清 $100 \mu \mathrm{L}$ に蒸
留水 $100 \mu \mathrm{L}$ を加えて混和し，その $5 \mu \mathrm{L}$ を LC-MS/ MS に供した。 また， $\beta$-グルクロニダーゼによる加 水分解は，尿 $100 \mu \mathrm{L}$ に $10 \%$ 䣷酸打よび $0.5 \mathrm{~mol} / \mathrm{L}$ の 酢酸緩衝液 (pH 5) を添加して pH 5 に調整した後,

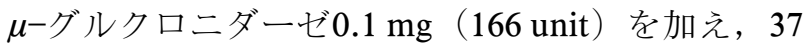
${ }^{\circ} \mathrm{C}$ の温浴中で 3 時間インキュベートして行った。 そ の後, 上述の方法でメタノールによる除タンパク処 理を行った後, 上清 $100 \mu \mathrm{L}$ に蒸留水 $100 \mu \mathrm{L}$ を加え て混和し，その $5 \mu \mathrm{L}$ を LC-MS/MS に供した。

\section{2 液一液抽出（定量分析用）}

尿 $100 \mu \mathrm{L}$ に, 内部標準物質として $\mathrm{EZ}-d 3$ 水溶液 (1 ng/mL) $100 \mu \mathrm{L}$ を添加し，10\%酢酸抢よび0.5 $\mathrm{mol} / \mathrm{L}$ の酢酸緩衝液（pH 5) を用いて $\mathrm{pH} 5$ に調 整した後, クロロホルム/2-プロパノール $(3: 1, \mathrm{v}$ /v） $1000 \mu \mathrm{L}$ を加えて擋拌した. その後, 遠心分離 (9000 rpm, $10 \mathrm{~min}, 4{ }^{\circ} \mathrm{C}$ ) を行った後, 有機層 （下層）を分取し，窒素気流下， $40{ }^{\circ} \mathrm{C} て ゙$ 穏やかに蒸 発乾固した. 得られた残さを $10 \%$ メタノール水溶液 $100 \sim 1000 \mu \mathrm{L}$ に再溶解した後， $5 \mu \mathrm{L}$ をLC-MS / MS に供した。 また， $\beta$-グルクロニダーゼによる加 水分解は，尿 $100 \mu \mathrm{L}$ に, EZ- $d 3$ 水溶液 $(1 \mathrm{ng} / \mathrm{mL})$ $100 \mu \mathrm{L}$ を添加した後， $10 \%$ 酢酸抢よび $0.5 \mathrm{~mol} / \mathrm{L}$ の 酢酸緩衝液（pH 5）を用いて $\mathrm{pH} 5$ に調整し， $\beta$ グルクロニダーゼ $0.1 \mathrm{mg}$ (166 unit) を加え, $37{ }^{\circ} \mathrm{C}$ の温浴中で 3 時間インキュベートして行った．その 後, 上述の方法で抽出, 蒸発乾固操作および再溶解 を行った後， $5 \mu \mathrm{L}$ をLC-MS/MS に供した。

有機溶媒の取り扱いはドラフト内で実施すると共 に, 各有機溶媒の廃棄は溶媒ごとに適切に行った。

\section{LC-MS/MS}

\section{1 定性分析および抱合体分析}

液体クロマトグラフに島津製作所製 Prominence, 質量分析装置に AB Sciex 製 Triple TOF 5600 を使用し，各成分のプロトン化分子をプリ カーサイオンとしてプロダクトイオンスペクトルの 測定を以下の条件で実施した。

カラム：化学物質評価研究機構製 $\mathrm{L}$-column2 ODS ( $1.5 \mathrm{~mm}$ i.d. $\times 150 \mathrm{~mm}$, 粒子径 $5 \mu \mathrm{m})$, 力 ラム温度 : $40{ }^{\circ} \mathrm{C}$, 移動相 A : $5 \%$ メタノール（10 $\mathrm{mmol} / \mathrm{L}$ 酢酸アンモニウム含有), 移動相 B : $95 \%$ メタノール $(10 \mathrm{mmol} / \mathrm{L}$ 酢酸アンモニウム含有 $)$, 
グラジエント条件 : B 0\%-リニアグラジエント（0$15 \mathrm{~min})-\mathrm{B} 100 \%(15-20 \mathrm{~min})$, 流速 : $0.1 \mathrm{~mL} /$ $\min$, ライン内径 : $130 \mu \mathrm{m}$, エレクトロード内径 : $100 \mu \mathrm{m}$, イオン化法 : エレクトロスプレーイオン 化（ESI） ポジティブモード，イオン化電圧 : 5.5 $\mathrm{kV}$ ，ターボスプレー温度 : $500{ }^{\circ} \mathrm{C}$, デクラスタリン グ電圧 $(\mathrm{DP}) ： 80 \mathrm{~V}$ ，コリジョンエネルギー $(\mathrm{CE})$ ： $35 \mathrm{eV}$.

質量校正は分析毎に外部標準法で実施し, 質量校 正用の標準試料として ESI ポジティブモード用の Positive Calibration Solution（AB Sciex 製）を用い た。

\section{2 定量分析およびインソース衝突誘起解離（In- Source CID）分析}

液体クロマトグラフに島津製作所製 Prominence, 質量分析装置に AB Sciex 製 QTRAP6500 を使用し，以下の条件で測定を実施した。

カラム：化学物質評価研究機構製 $\mathrm{L}$-column2 ODS $(1.0 \mathrm{~mm}$ i.d. $\times 50 \mathrm{~mm}$, 粒子径 $3 \mu \mathrm{m})$, カラ ム温度 : $40{ }^{\circ} \mathrm{C}$, 移動相 $\mathrm{A}: 5 \%$ メタノール (10 $\mathrm{mmol} / \mathrm{L}$ 酢酸アンモニウム含有, 組成 : メタノール $50 \mathrm{~mL}+$ 超純水 $940 \mathrm{~mL}+1 \mathrm{~mol} / \mathrm{L}$ 酢酸アンモニウム $10 \mathrm{~mL})$, 移動相 B : $95 \%$ メタノール $(10 \mathrm{mmol} / \mathrm{L}$ 酢酸アンモニウム含有, 組成 : メタノール $950 \mathrm{~mL}$ +超純水 $40 \mathrm{~mL}+1 \mathrm{~mol} / \mathrm{L}$ 酢酸アンモニウム 10 $\mathrm{mL})$, グラジエント条件 : B 0\%-リニアグラジエン 卜 $(0-10 \mathrm{~min})-\mathrm{B} 100 \%(10-20 \mathrm{~min})$, 流速 : 0.05 $\mathrm{mL} / \mathrm{min}$, ライン内径 : $50 \mu \mathrm{m}$, エレクトロード内 径 : $50 \mu \mathrm{m}$, イオン化法 : ESI ポジティブモード, イオン化電圧 : $5.5 \mathrm{kV}$, ターボスプレー温度 : 500 ${ }^{\circ} \mathrm{C}$.

定量分析は選択反応モニタリング（SRM）によ り実施し, 各成分の SRM トランジションは, Table 1 に示すように, プロトン化分子をプリカーサ イオンとし，各成分の構造を反映したプロダクトイ オンを選択して構築した。

In-Source CID 分析は, DP 250 V, プリカーサ イオンを $m / z 359.1$ (EZ-M3 および EZ-M6 のプ ロトン化分子), $\mathrm{CE}$ を $35 \mathrm{eV}$ に設定し，プロダクト イオンスキャンを実施した。
Table 1 Optimized SRM parameters of EZ, EZ-M3, RZ-M6 and an internal standard (IS).

\begin{tabular}{lcccccc}
\hline Compound & $\begin{array}{c}\mathrm{Q} 1 \\
(\mathrm{~m} / \mathrm{z})\end{array}$ & $\begin{array}{c}\mathrm{Q} 3 \\
(\mathrm{~m} / \mathrm{z})\end{array}$ & $\begin{array}{c}\mathrm{DP} \\
(\mathrm{V})\end{array}$ & $\begin{array}{c}\mathrm{EP} \\
(\mathrm{V})\end{array}$ & $\begin{array}{c}\mathrm{CE} \\
(\mathrm{eV})\end{array}$ & $\begin{array}{c}\mathrm{CXP} \\
(\mathrm{V})\end{array}$ \\
\hline EZ & 343.1 & $\underline{314.1}$ & 91 & 10 & 31 & 6 \\
& & $\underline{259.1}$ & 91 & 10 & 45 & 6 \\
\hline EZ-M3 & 359.1 & $\underline{341.1}$ & 81 & 10 & 27 & 6 \\
& & $\underline{315.1}$ & 81 & 10 & 27 & 6 \\
\hline EZ-M6 & 359.1 & $\underline{286.1}$ & 96 & 10 & 31 & 6 \\
& & $\underline{341.1}$ & 96 & 10 & 43 & 6 \\
\hline EZ- $d_{3}$ (IS) & 346.1 & $\underline{317.1}$ & 91 & 10 & 31 & 6 \\
\hline
\end{tabular}

The transition for quantification is underlined. Q1, quadrupole 1; Q3, quadrupole 3; DP, declustering potential; $\mathrm{EP}$, entrance potential; $\mathrm{CE}$, collision energy; CXP, collision cell exit potential; EZ, etizolam; EZ-M3, 8- $\alpha$-hydroxyetizolam; EZ-M6, 1-hydroxyetizolam; EZ- $d 3$, etizolam- $d 3$.

\section{結果および考察 \\ 1. $\mathbf{E Z}$ および代謝物の検出}

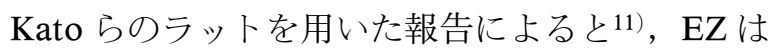
摂取量の約 $30 \%$ が尿中に排泄され，その多くは代謝 物として排泄されることが示されている。代謝物と しては， 8 位エチル基 $\alpha$-水酸化体（EZ-M3）打よ び 1 位メチル基水酸化体（EZ-M6）が同定されて おり，これらはさらに第二相代謝（グルクロン酸抱 合）を受けることが， $\beta$-グルクロニダーゼによる 加水分解により間接的に確認されている. 一方, ヒ 卜においても代謝物の検出例が報告されており, EZ と共に EZ-M3 および EZ-M6 が検出されてい る ${ }^{12,13)}$. 特に主代謝物は EZ-M3 と考えられてお り，これを摂取証明の指標として，いくつかの分析 法が推奨されている14,15).

本研究では，第一相代謝物である EZ-M3 および EZ-M6 と共に，これまで直接検出の報告がない第 二相代謝物（抱合体）をターゲットとして, EZ 単 回摂取者の尿を対象に代謝物の探索を行った。その 結果を Fig. 1 に示す. 未変化体 EZ が17.2分に検出 されると共に，EZ-M3 および EZ-M6が，それぞ れ15.1分および16.4分に検出され，いずれも標準物 質の保持時間および質量スペクトルによく一致し た。さらに，EZ-M3 および EZ-M6の抱合体を探 
(A) Before enzymatic hydrolysis
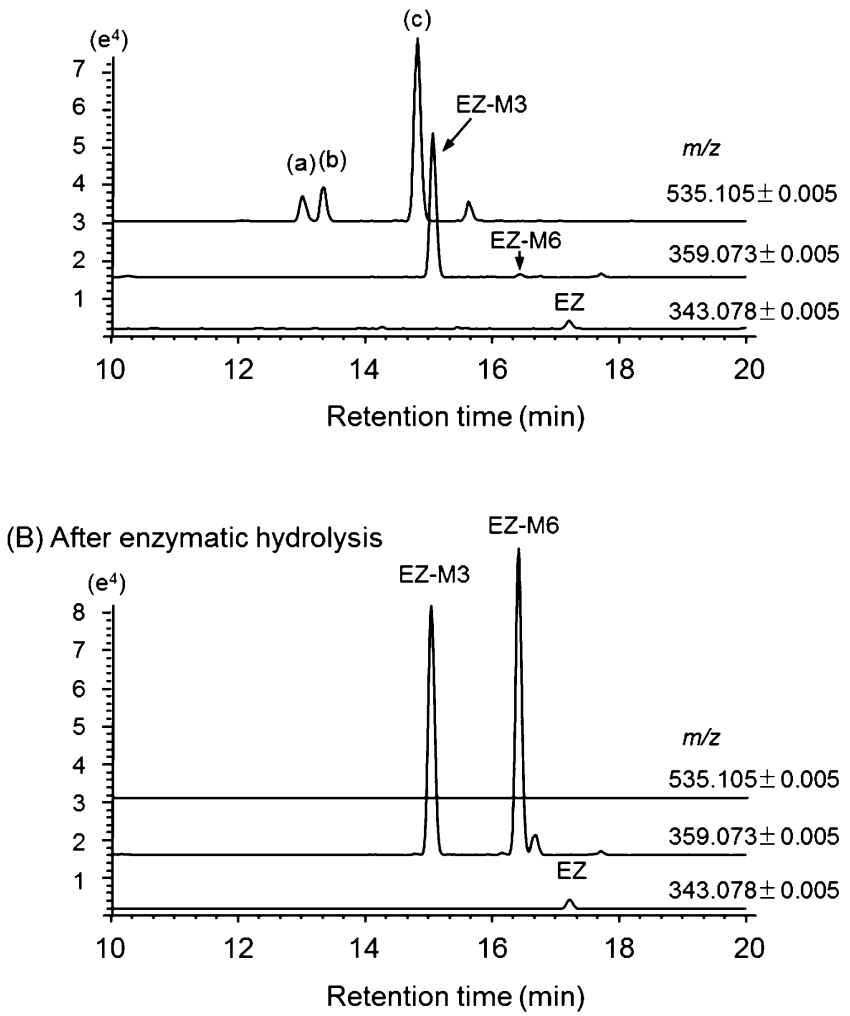

(C)
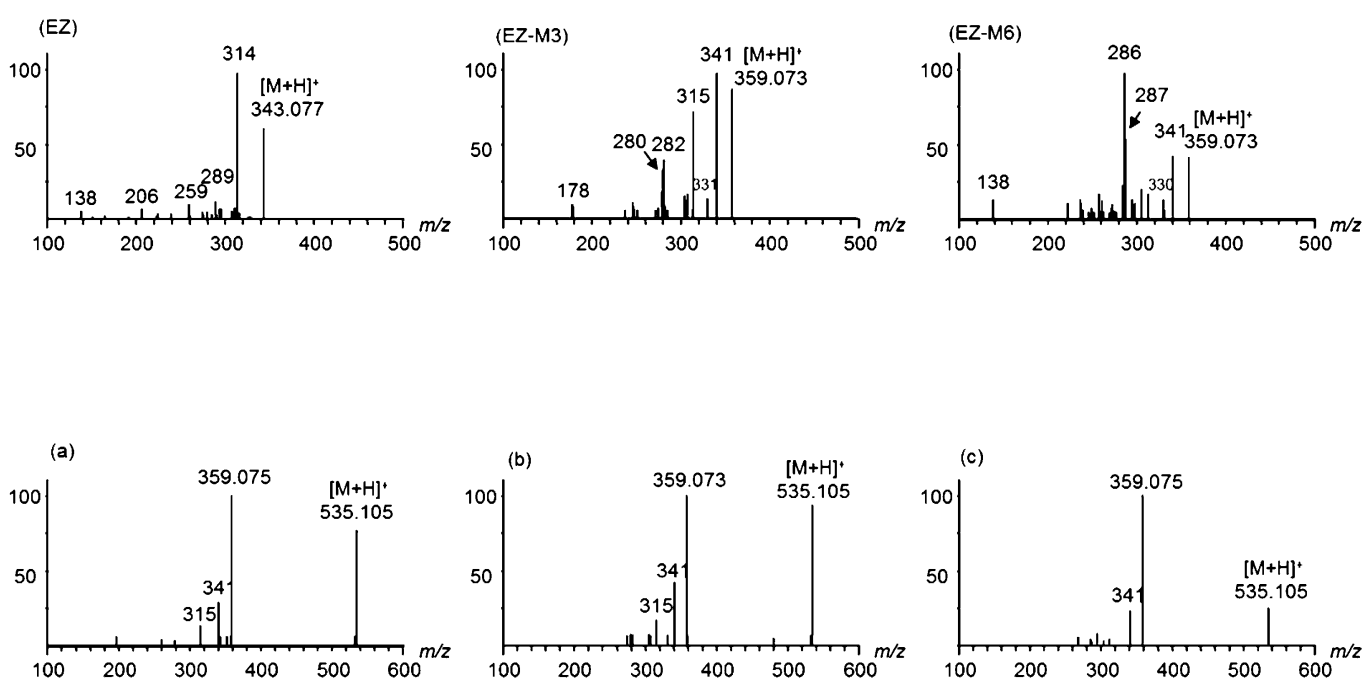

Fig. 1 Extracted ion chromatograms obtained from an urine specimen collected from Subject 3 (8-11 h) (A) before and (B) after enzymatic hydrolysis, and (C) product ion mass spectra of EZ and its metabolites obtained by liquid chromatography-high-resolution tandem mass spectrometry (LC-HR-MS-MS). Each protonated molecule was selected as a precursor ion.

EZ, etizolam; EZ-M3, 8- $\alpha$-hydroxyetizolam; EZ-M6, 1-hydroxyetizolam; (a), EZ-M3-glucuronide 1 (EZM3-G1); (b), EZ-M3-glucuronide 2 (EZ-M3-G2); (c), EZ-M6-glucuronide (EZ-M6-G). 
索したところ, 硫酸抱合体は不検出であったもの の，グルクロン酸抱合体と考えられる 3 つのピーク (Peaks (a)-(c), 各成分のプロトン化分子 : Peak (a), $m / z$ 535.1054; Peak (b), $m / z$ 535.1051; Peak (c), $m / z 535.1053)$ が検出され, グルクロン酸抱合 体のプロトン化分子の計算精密質量 $\left(\left[\mathrm{C}_{23} \mathrm{H}_{24} \mathrm{ClN}_{4} \mathrm{O}_{7} \mathrm{~S}\right]^{+}\right.$: 535.1049) との誤差はいずれ も $1 \mathrm{ppm}$ 未満であった。 また，それらのプロトン 化分子 $(m / z 535.1)$ をプリカーサイオンとして測 定したプロダクトイオンスペクトルには, グルクロ ン酸が脱離したアグリコン（EZ-M3 抢よび EZM6) 由来のイオン $(m / z 359.073 \sim 359.075)$ なら びにそれらに特徵的なプロダクトイオン $(\mathrm{m} / \mathrm{z} 341)$ が併せて観察された（Fig. 1C）。しかしながら， EZ-M3 および EZ-M6 は構造異性体の関係にある ため，上記イオン以外に各アグリコンに特徵的なイ オンが観察されなかったプロダクトイオンスペクト ルのみではピーク (a)-(c)が， EZ-M3 および EZM6のいずれのグルクロン酸抱合体であるかを特定
することは困難であった，そこで, In-Source CID 法によって，ピーク (a)-(c)のアグリコンの特定を 試みた。インソースに拈いて高電压（DP: $250 \mathrm{~V}$ ) を印加し，グルクロン酸を脱離させて得られるアグ リコン $(m / z 359.1)$ をプリカーサイオンとしてプ ロダクトイオンスキャンを実施した。その結果, ピーク (a) 抢よび (b) は EZ-M3，ならびにピーク (c) は EZ-M6 のプロダクトイオンスペクトルと良 く一致したため, ピーク (a) および(b)は EZ-M3の グルクロン酸抱合体（ピーク（a）: EZ-M3glucuronide-1 (EZ-M3-G1), ピーク (b): EZ-M3glucuronide-2 (EZ-M3-G2)), ならびにピーク (c) は EZ-M6のグルクロン酸抱合体（EZ-M6glucuronide (EZ-M6-G)) であることが推定され た（Fig. 2)。な打，EZ-M3 は不斉炭素を有するた め，これに D-グルクロン酸が付加することによっ て，ジアステレオマー(EZ-M3-G1 および EZ-M3G2）として2成分にピーク分離して検出されたも のと考えられる.
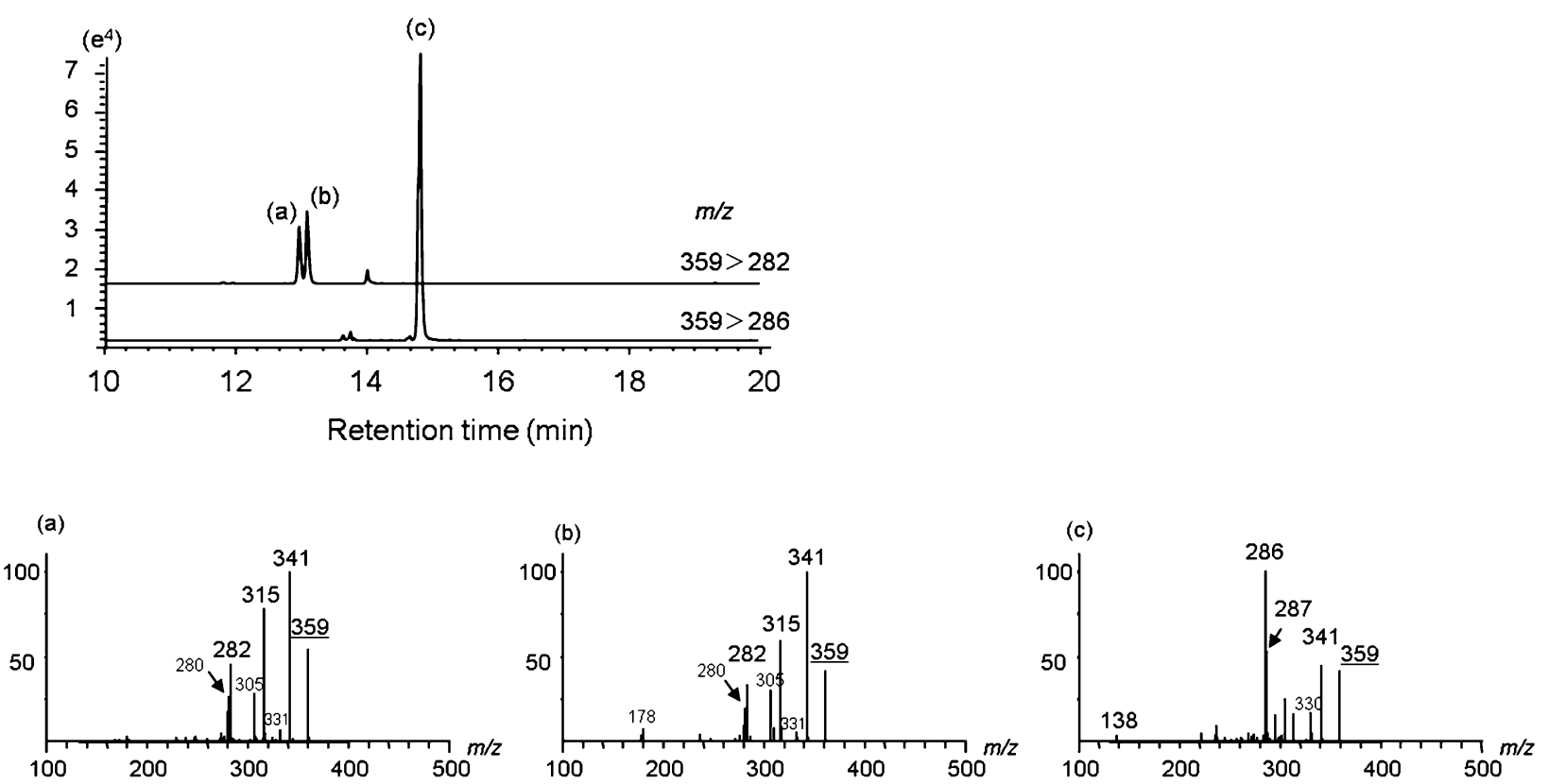

Fig. 2 Extracted ion chromatograms obtained from an urine specimen collected from Subject $3(8-11 \mathrm{~h})$ and product ion mass spectra of peaks $(\mathrm{a})-(\mathrm{c})$ obtained by liquid chromatography-tandem mass spectrometry (LC-MS-MS). Each aglycone $(\mathrm{m} / z$ 359.1) of the glucuronides was selected as a precursor ion. Declustering potential (DP) and collision energy $(\mathrm{CE})$ were set at $250 \mathrm{~V}$ and $35 \mathrm{eV}$, respectively.

(a), EZ-M3-glucuronide 1 (EZ-M3-G1); (b), EZ-M3-glucuronide 2 (EZ-M3-G2); (c), EZ-M6glucuronide (EZ-M6-G). 
<smiles>CCc1cc2c(s1)-n1c(C)nnc1CN=C2c1ccccc1Cl</smiles>

EZ

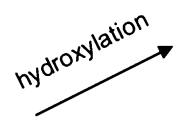<smiles>Cc1nnc2n1-c1sc(C(C)O)cc1C(c1ccccc1Cl)=NC2</smiles>

EZ-M3

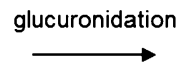

glucuronidation<smiles>Cc1nnc2n1-c1sc([C@H](C)O[AlH2])cc1C(c1ccccc1Cl)=NC2</smiles>

EZ-M3-G1, EZ-M3-G2

(Diastereomers)<smiles>CCc1cc2c(s1)-n1c(nnc1CO[AlH2])CN=C2c1ccccc1Cl</smiles>

EZ-M6-G

Fig. 3 Proposed metabolic pathways for EZ in humans.

EZ, etizolam; EZ-M3, 8- $\alpha$-hydroxyetizolam; EZ-M6, 1-hydroxyetizolam; EZ-M3-G1, EZ-M3glucuronide 1; EZ-M3-G2, EZ-M3-glucuronide 2; EZ-M6-G, EZ-M6-glucuronide.

また， $\beta$-グルクロニダーゼでの加水分解によっ てピーク (a)-(c)はいずれも消失し，EZ-M3 および EZ-M6の有意な増加が確認された（Fig. 1).この ことは，これらのピークが EZ-M3 および EZ-M6 のグルクロン酸抱合体であることを強く支持するも のである.

従って, EZの代謝経路は Fig. 3 に示す通りであ ると考えられる.

\section{2. 分析バリデーション}

EZ，EZ-M3 および EZ-M6の定量分析に先立 ち，本法のバリデーションを実施した（Table 2). 回収率はいずれの成分も $90 \%$ 以上，検出限界（S/N 5）抢よび定量限界（ $\mathrm{S} / \mathrm{N} \geqq 10 ）$ はそれぞれ0.05 $\mathrm{ng} / \mathrm{mL}$ 抢よび $0.1 \mathrm{ng} / \mathrm{mL}$ であった。検量線は 0.1 $300 \mathrm{ng} / \mathrm{mL}$ の範囲で良好な直線性を示したほか， 真度および精度はそれぞれ $11 \%$ および 7\%未満で， 定量值の信頼性を十分に担保できる良好な結果が得 られた．尿から抽出された夾雑物によるイオンサプ レッションは 5\%未満であり，本法はマトリックス による影響が少ないことが示された。

\section{3. $\mathbf{E Z}$ 単回摂取後の尿中排泄プロファイル}

\subsection{EZ， EZ-M3 および EZ-M6 の濃度推移}

本研究では EZ 錠 $(1 \mathrm{mg})$ の単回摂取者 3 名 (30 および40歳代の男性）について，摂取後最長 215 時 間にわたって採尿を実施し, 当尿試料について酵素 加水分解を行わずに定量分析を実施した．その結果 を Table 3 に示す. 未変化体 EZ については，摂取 後 7 あるいは 8 時間までに最高濃度（3.1-3.8 ng/ $\mathrm{mL}$ ）に達し, その後は徐々に減少して, 摂取後 32 -44時間で本法の検出限界である $0.05 \mathrm{ng} / \mathrm{mL}$ 付近に まで減少した。また，代謝物である EZ-M6も， $\mathrm{EZ}$ と同様の濃度レベルで, 摂取後 7〜16時間まで に最高濃度 (1.4-3.2 ng/mL) に達した後, 摂取後 38-48時間には検出限界 $(0.05 \mathrm{ng} / \mathrm{mL})$ 付近にまで 減少した。一方, EZ-M3 は最高濃度が46-81 ng/ $\mathrm{mL}$ で, $\mathrm{EZ}$ および $\mathrm{EZ}-\mathrm{M} 6$ と比較して高濃度で あったほか，摂取後32-36時間で最高濃度に達する 被験者（Subject 2）もあり，最高濃度に到達する 時間の個人差が比較的大きかった．また，いずれの 被験者においても, 時間経過に伴う濃度減少は緩や 
Table 2 Validation data for the LC-MS-MS procedure established in the present study.

\begin{tabular}{|c|c|c|c|}
\hline & \multicolumn{3}{|c|}{ Analyte } \\
\hline & $\mathrm{EZ}$ & EZ-M3 & EZ-M6 \\
\hline \multicolumn{4}{|l|}{ Recovery $(\%)^{a)}$} \\
\hline$(10 \mathrm{ng} / \mathrm{mL})$ & $110 \pm 4$ & $94 \pm 9$ & $109 \pm 15$ \\
\hline$(100 \mathrm{ng} / \mathrm{mL})$ & $101 \pm 8$ & $96 \pm 4$ & $95 \pm 7$ \\
\hline Correlation coefficient $(r)^{b)}$ & 0.999 & 0.999 & 0.999 \\
\hline \multicolumn{4}{|l|}{ Accuracy relative error $(\%)$} \\
\hline \multicolumn{4}{|l|}{ Intra-day } \\
\hline$(0.5 \mathrm{ng} / \mathrm{mL})$ & 6.8 & -4.3 & 4.6 \\
\hline$(5 \mathrm{ng} / \mathrm{mL})$ & -1.4 & 1.4 & -1.3 \\
\hline$(50 \mathrm{ng} / \mathrm{mL})$ & 3.2 & -0.6 & 2.1 \\
\hline \multicolumn{4}{|l|}{ Inter-day } \\
\hline$(0.5 \mathrm{ng} / \mathrm{mL})$ & 5.2 & 4.2 & 10.0 \\
\hline$(5 \mathrm{ng} / \mathrm{mL})$ & -0.8 & 10.1 & 8.3 \\
\hline$(50 \mathrm{ng} / \mathrm{mL})$ & -6.1 & 0.6 & 7.1 \\
\hline \multicolumn{4}{|l|}{ Precision RSD (\%) } \\
\hline \multicolumn{4}{|l|}{ Intra-day } \\
\hline$(0.5 \mathrm{ng} / \mathrm{mL})$ & 2.6 & 3.4 & 3.4 \\
\hline$(5 \mathrm{ng} / \mathrm{mL})$ & 4.9 & 2.7 & 3.1 \\
\hline$(50 \mathrm{ng} / \mathrm{mL})$ & 6.5 & 4.3 & 3.7 \\
\hline \multicolumn{4}{|l|}{ Inter-day } \\
\hline$(0.5 \mathrm{ng} / \mathrm{mL})$ & 3.8 & 7.1 & 4.1 \\
\hline$(5 \mathrm{ng} / \mathrm{mL})$ & 5.3 & 1.8 & 2.6 \\
\hline$(50 \mathrm{ng} / \mathrm{mL})$ & 3.8 & 6.8 & 5.3 \\
\hline
\end{tabular}

EZ, etizolam; EZ-M3, 8- $\alpha$-hydroxyetizolam; EZM6, 1-hydroxyetizolam.

a) The recoveries were calculated by comparing peak areas of the analytes extracted from spiked samples with those spiked in urinary extract $(\mathrm{n}=5)$.

b) Linearity ranges were tested with eight different concentrations $(0.1-300 \mathrm{ng} / \mathrm{mL})$ of analytes spiked into drug-free urine.

かで, 摂取後50時間付近においても $10 \mathrm{ng} / \mathrm{mL}$ 以上 の濃度で検出され，摂取後 6 7 日まで検出が可能 であった（検出限界：0.05 ng/mL). Fracasso らの 報告によると ${ }^{16)}, \mathrm{EZ}-\mathrm{M} 3$ の血中消失半減期（ $\left.\mathrm{t}_{1 / 2}\right)$ は8.2時間 $(\mathrm{n}=5)$ であり, $\mathrm{EZ} の \mathrm{t}_{1 / 2}$ (3.4時間, $\mathrm{n}$ =5）と比較して有意に長いことが示されているた め, EZ-M3 の尿中濃度の緩やかな減少は, EZ-M3 の $\mathrm{t}_{1 / 2}$ に相関していることが示唆された.

また, 摂取量 (EZ $1 \mathrm{mg})$ に対する各成分の累積
排泄量の割合 (モル換算) は, EZ が0.15-0.27\%, EZ-M3 が 10-13\%， EZ-M6 が 0.10-0.14\%であり (Table 3)，EZ-M3 は遊離体として尿中に排泄され る量が多く, 摂取後 6-7 日まで検出が可能であっ た.

さらに，尿中に排泄されるグルクロン酸抱合体の 割合を検討するために，各被験者の尿試料 1 点ずつ (Subject 1, 8-12 h; Subject 2, 7-11 h; Subject 3, 8$11 \mathrm{~h})$ について, 酵素加水分解後に定量分析を実施 したところ, Table 3 に示すように，加水分解前と 比較して, $\mathrm{EZ}-\mathrm{M} 3$ は2.0 2.2倍に増加し（加水分 解前: $33 \sim 74 \mathrm{ng} / \mathrm{mL}$ ，加水分解後 : $73 \sim 150 \mathrm{ng} /$ $\mathrm{mL}$ )，EZ-M6 は80〜160倍に増加した（加水分解 前： $0.70 \sim 1.1 \mathrm{ng} / \mathrm{mL}$ ，加水分解後：56〜180 ng/ $\mathrm{mL})$. EZ-M6 はほとんぞがグルクロン酸抱合体と して尿中に排泄されることが示され，被験者や摂取 後の時間帯によっては, 加水分解することにより EZ-M3 よりも高濃度で検出されることが示され た.

\section{2 グルクロン酸抱合体の濃度推移}

本研究では，EZ-M3 および EZ-M6 と共に，そ れらのグルクロン酸抱合体 (EZ-M3-G1, EZ-M3G2，EZ-M6-G）を初めて直接検出した。 そこで, 各グルクロン酸抱合体の濃度推移についても検討す るために，Triple TOF 5600 を用いて，プロトン化 分子 $(m / z 535.105)$ の面積值を, 摂取後概ね 250 時 間まで経時的に測定した（Table 4)。また，前項で 酵素加水分解を実施した試料について，加水分解前 後の EZ-M3 抢よび EZ-M6の濃度増加分に基づ き，以下の計算式により間接的にグルクロン酸抱合 体の濃度を算出した（Table 4，［］内の数值). なお，EZ-M3-G1 および EZ-M3-G2 については， LC-MS/MS に対する検出感度が同等と仮定して各 濃度を算出した。

- [EZ-M3-G1 の濃度 $]=[\mathrm{EZ}-\mathrm{M} 3$ の濃度増加分 $] \times$ [EZ-M3-G1 の分子量 (534) / EZ-M3 の分子量 (358) $] \times[(\mathrm{EZ}-\mathrm{M} 3-\mathrm{G} 1$ の面積值) / (EZ-M3-G1 の面積值 $+\mathrm{EZ}-\mathrm{M} 3-\mathrm{G} 2$ の面積値) ]

- [EZ-M3-G2 の濃度 $]=[E Z-M 3$ の濃度増加分 $] \times$ [EZ-M3-G2 の分子量 (534)/EZ-M3 の分子量 (358) $] \times[(\mathrm{EZ}-\mathrm{M} 3-\mathrm{G} 2$ の面積值 $) /(\mathrm{EZ}-\mathrm{M} 3-\mathrm{G} 1$ 


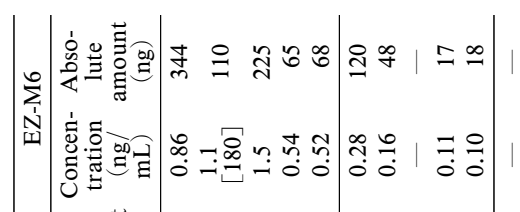

空

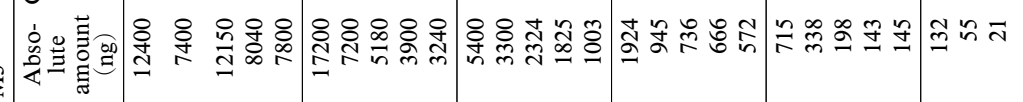

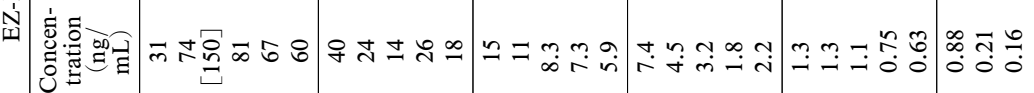

$\stackrel{\dot{00}}{\Xi}$

N

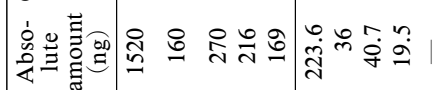

它.

N

4

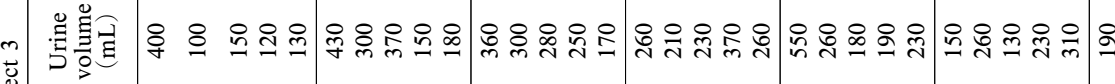

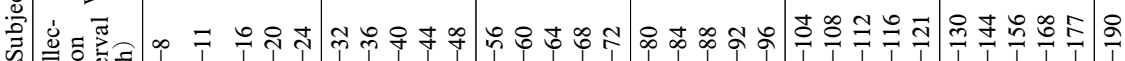

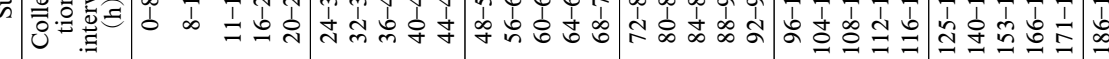

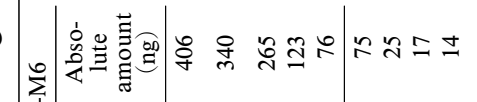

N

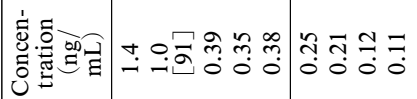

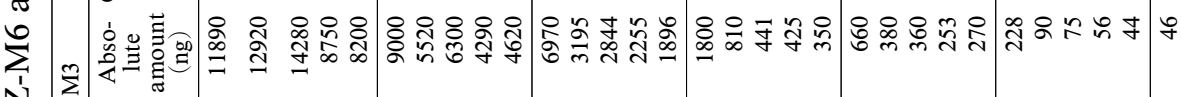

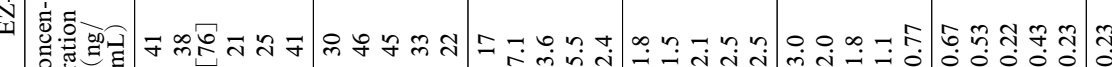

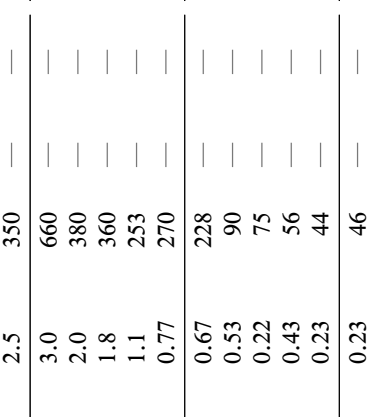

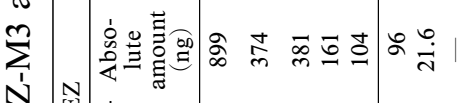

N $N$

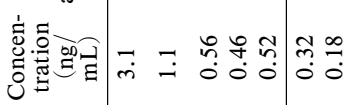

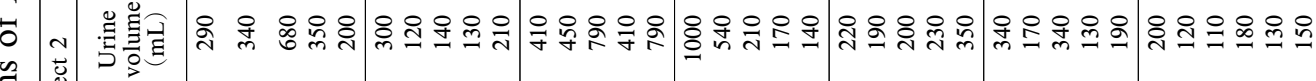

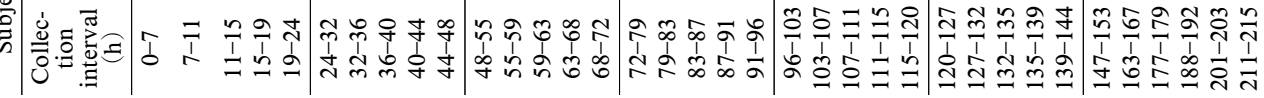

$\stackrel{7}{\stackrel{0}{0}}$

후을

กิ่

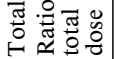

胥

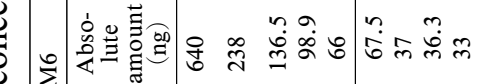

넙

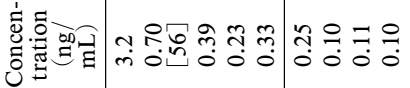

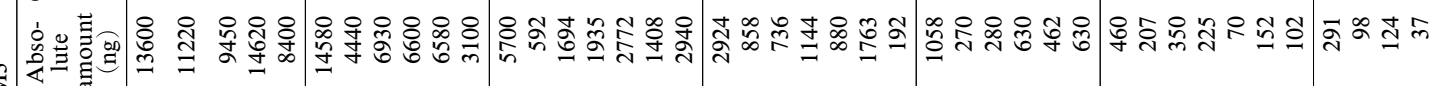

m

党

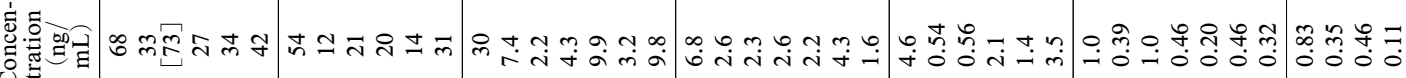

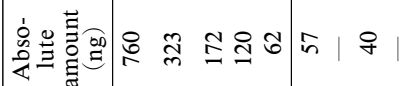

N

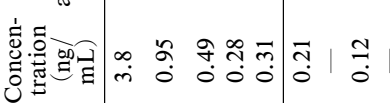

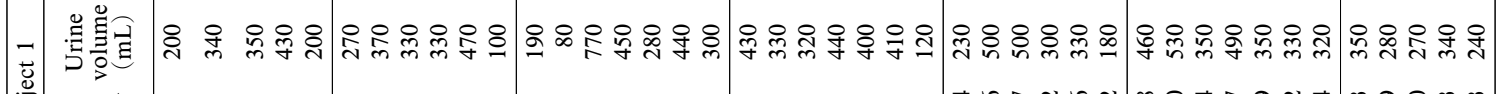

กั๊

80

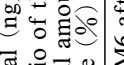

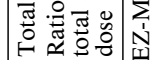

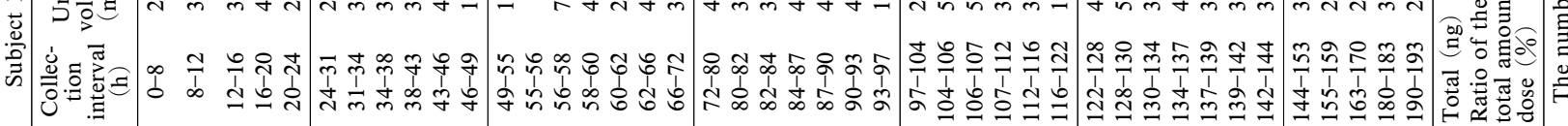

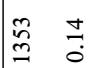

홍

กำ 
Table 4 Estimated concentrations of glucuronides in urine after a single ingestion of EZ.

\begin{tabular}{|c|c|c|c|c|c|c|c|c|c|c|}
\hline \multicolumn{2}{|c|}{ Subject 1} & \multicolumn{3}{|c|}{ EZ-M3-G1 } & \multicolumn{3}{|c|}{ EZ-M3-G2 } & \multicolumn{3}{|c|}{ EZ-M6-G } \\
\hline $\begin{array}{l}\text { Collection } \\
\text { interval } \\
(\mathrm{h})\end{array}$ & $\begin{array}{l}\text { Urine } \\
\text { volume } \\
(\mathrm{mL})\end{array}$ & $\begin{array}{c}\text { Area } \\
{[\mathrm{M}+\mathrm{H}]^{+}}\end{array}$ & $\begin{array}{c}\text { Estimated } \\
\text { concentration } \\
(\mathrm{ng} / \mathrm{mL})\end{array}$ & $\begin{array}{l}\text { Absolute } \\
\text { amount } \\
(\text { ng) }\end{array}$ & $\begin{array}{c}\text { Area } \\
{[\mathrm{M}+\mathrm{H}]^{+}}\end{array}$ & $\begin{array}{c}\text { Estimated } \\
\text { concentration } \\
(\mathrm{ng} / \mathrm{mL})\end{array}$ & $\begin{array}{l}\text { Absolute } \\
\text { amount } \\
\text { (ng) }\end{array}$ & $\begin{array}{c}\text { Area } \\
{[\mathrm{M}+\mathrm{H}]^{+}}\end{array}$ & $\begin{array}{c}\text { Estimated } \\
\text { concentration } \\
(\mathrm{ng} / \mathrm{mL})\end{array}$ & $\begin{array}{c}\text { Absolute } \\
\text { amount } \\
\text { (ng) }\end{array}$ \\
\hline $0-8$ & 200 & 85500 & 71 & 14200 & 101000 & 83 & 16600 & 565000 & 350 & 70000 \\
\hline $8-12$ & 340 & 43500 & {$[36]$} & 12240 & 28000 & {$[23]$} & 7820 & 133000 & {$[82]$} & 27880 \\
\hline $12-16$ & 350 & 33700 & 28 & 9800 & 20700 & 17 & 5950 & 76400 & 47 & 16450 \\
\hline $16-20$ & 430 & 28000 & 23 & 9890 & 11400 & 9.4 & 4042 & 43200 & 27 & 11610 \\
\hline $20-24$ & 200 & 56200 & 47 & 9400 & 21200 & 17 & 3400 & 59300 & 37 & 7400 \\
\hline $24-31$ & 270 & 64700 & 54 & 14580 & 24200 & 20 & 5400 & 43300 & 27 & 7290 \\
\hline $31-34$ & 370 & 13900 & 12 & 4440 & 2700 & 2.2 & 814 & 6400 & 3.9 & 1443 \\
\hline $34-38$ & 330 & 23100 & 19 & 6270 & 5900 & 4.8 & 1584 & 11800 & 7.3 & 2409 \\
\hline $38-43$ & 330 & 24200 & 20 & 6600 & 5000 & 4.1 & 1353 & 8900 & 5.5 & 1815 \\
\hline $43-46$ & 470 & 11100 & 9.2 & 4324 & 2700 & 2.2 & 1034 & 2100 & 1.3 & 611 \\
\hline $46-49$ & 100 & 38900 & 32 & 3200 & 9200 & 7.6 & 760 & 6700 & 4.1 & 410 \\
\hline Total (ng) & & & & 94944 & & & 48757 & & & 147318 \\
\hline $\begin{array}{l}\text { Ratio of } d \\
\text { amounts } t \\
(\%)\end{array}$ & $\begin{array}{l}\text { letected } \\
\text { o dose }\end{array}$ & & & 6.1 & & & 3.1 & & & 9.4 \\
\hline
\end{tabular}

\begin{tabular}{|c|c|c|c|c|c|c|c|c|c|c|}
\hline \multicolumn{2}{|c|}{ Subject 2} & \multicolumn{3}{|c|}{ EZ-M3-G1 } & \multicolumn{3}{|c|}{ EZ-M3-G2 } & \multicolumn{3}{|c|}{ EZ-M6-G } \\
\hline $\begin{array}{l}\text { Collection } \\
\text { interval } \\
(\mathrm{h}) \\
\end{array}$ & $\begin{array}{c}\text { Urine } \\
\text { volume } \\
(\mathrm{mL})\end{array}$ & $\begin{array}{c}\text { Area } \\
{[\mathrm{M}+\mathrm{H}]^{+}}\end{array}$ & $\begin{array}{c}\text { Estimated } \\
\text { concentration } \\
(\mathrm{ng} / \mathrm{mL})\end{array}$ & $\begin{array}{c}\text { Absolute } \\
\text { amount } \\
(\mathrm{ng})\end{array}$ & $\begin{array}{c}\text { Area } \\
{[\mathrm{M}+\mathrm{H}]^{+}}\end{array}$ & $\begin{array}{c}\text { Estimated } \\
\text { concentration } \\
(\mathrm{ng} / \mathrm{mL})\end{array}$ & $\begin{array}{c}\text { Absolute } \\
\text { amount } \\
(\mathrm{ng})\end{array}$ & $\begin{array}{c}\text { Area } \\
{[\mathrm{M}+\mathrm{H}]^{+}}\end{array}$ & $\begin{array}{c}\text { Estimated } \\
\text { concentration } \\
(\mathrm{ng} / \mathrm{mL})\end{array}$ & $\begin{array}{c}\text { Absolute } \\
\text { amount } \\
(\mathrm{ng})\end{array}$ \\
\hline $0-7$ & 290 & 33300 & 28 & 8120 & 56300 & 47 & 13630 & 354000 & 230 & 66700 \\
\hline $7-11$ & 340 & 31300 & {$[26]$} & 8840 & 37100 & {$[31]$} & 10540 & 203000 & {$[130]$} & 44200 \\
\hline $11-15$ & 680 & 18300 & 15 & 10200 & 16700 & 14 & 9520 & 56400 & 36 & 24480 \\
\hline $15-19$ & 350 & 31400 & 26 & 9100 & 20500 & 17 & 5950 & 77300 & 50 & 17500 \\
\hline $19-24$ & 200 & 69300 & 58 & 11600 & 37200 & 31 & 6200 & 110000 & 70 & 14000 \\
\hline $24-32$ & 300 & 52300 & 43 & 12900 & 23400 & 20 & 6000 & 44600 & 29 & 8700 \\
\hline $32-36$ & 120 & 67700 & 56 & 6720 & 30900 & 26 & 3120 & 65100 & 42 & 5040 \\
\hline $36-40$ & 140 & 43300 & 36 & 5040 & 18000 & 15 & 2100 & 30800 & 20 & 2800 \\
\hline $40-44$ & 130 & 39100 & 32 & 4160 & 17300 & 15 & 1950 & 20700 & 13 & 1690 \\
\hline $44-48$ & 210 & 16600 & 14 & 2940 & 6600 & 6.0 & 1260 & 9900 & 6.3 & 1323 \\
\hline \multirow{2}{*}{\multicolumn{2}{|c|}{$\begin{array}{l}\text { Total (ng) } \\
\text { Ratio of detected } \\
\text { amounts to dose } \\
(\%)\end{array}$}} & & & 79620 & & & 60270 & & & 186433 \\
\hline & & & & 5.1 & & & 3.9 & & & 12 \\
\hline
\end{tabular}

\begin{tabular}{|c|c|c|c|c|c|c|c|c|c|c|}
\hline \multicolumn{2}{|c|}{ Subject 3} & \multicolumn{3}{|c|}{ EZ-M3-G1 } & \multicolumn{3}{|c|}{ EZ-M3-G2 } & \multicolumn{3}{|c|}{ EZ-M6-G } \\
\hline $\begin{array}{l}\text { Collection } \\
\text { interval } \\
(\mathrm{h})\end{array}$ & $\begin{array}{c}\text { Urine } \\
\text { volume } \\
(\mathrm{mL})\end{array}$ & $\begin{array}{c}\text { Area } \\
{[\mathrm{M}+\mathrm{H}]^{+}}\end{array}$ & $\begin{array}{c}\text { Estimated } \\
\text { concentration } \\
(\mathrm{ng} / \mathrm{mL})\end{array}$ & $\begin{array}{c}\text { Absolute } \\
\text { amount } \\
(\mathrm{ng})\end{array}$ & $\begin{array}{c}\text { Area } \\
{[\mathrm{M}+\mathrm{H}]^{+}}\end{array}$ & $\begin{array}{c}\text { Estimated } \\
\text { concentration } \\
(\mathrm{ng} / \mathrm{mL})\end{array}$ & $\begin{array}{l}\text { Absolute } \\
\text { amount } \\
(\mathrm{ng})\end{array}$ & $\begin{array}{c}\text { Area } \\
{[\mathrm{M}+\mathrm{H}]^{+}}\end{array}$ & $\begin{array}{c}\text { Estimated } \\
\text { concentration } \\
(\mathrm{ng} / \mathrm{mL})\end{array}$ & $\begin{array}{c}\text { Absolute } \\
\text { amount } \\
(\mathrm{ng})\end{array}$ \\
\hline $0-8$ & 400 & 34600 & 29 & 11600 & 61300 & 51 & 20400 & 389000 & 240 & 96000 \\
\hline $8-11$ & 100 & 60000 & {$[51]$} & 5100 & 75900 & {$[63]$} & 6300 & 432000 & {$[270]$} & 27000 \\
\hline $11-16$ & 150 & 91400 & 78 & 11700 & 93500 & 78 & 11700 & 421000 & 260 & 39000 \\
\hline $16-20$ & 120 & 65100 & 55 & 6600 & 70300 & 58 & 6960 & 291000 & 180 & 21600 \\
\hline $20-24$ & 130 & 44400 & 38 & 4940 & 38300 & 32 & 4160 & 149000 & 93 & 12090 \\
\hline $24-32$ & 430 & 32200 & 27 & 11610 & 22800 & 19 & 8170 & 64800 & 41 & 17630 \\
\hline $32-36$ & 300 & 15900 & 14 & 4200 & 8100 & 6.7 & 2010 & 27500 & 17 & 5100 \\
\hline $36-40$ & 370 & 11500 & 10 & 3700 & 6600 & 5.5 & 2035 & 14100 & 8.8 & 3256 \\
\hline $40-44$ & 150 & 18800 & 16 & 2400 & 13100 & 11 & 1650 & 22300 & 14 & 2100 \\
\hline $44-48$ & 180 & 8500 & 7.2 & 1296 & 7300 & 6.1 & 1098 & 6900 & 4.3 & 774 \\
\hline \multirow{2}{*}{\multicolumn{2}{|c|}{$\begin{array}{l}\text { Total (ng) } \\
\text { Ratio of detected } \\
\text { amounts to dose } \\
(\%)\end{array}$}} & & & 63146 & & & 64483 & & & 224550 \\
\hline & & & & 4.0 & & & 4.1 & & & 14 \\
\hline
\end{tabular}

The numbers in parentheses were calculated based on increased amounts of EZ-M3 and EZ-M6 after enzymatic hydrolysis. EZ, etizolam; EZ-M3, 8- $\alpha$-hydroxyetizolam; EZ-M6, 1-hydroxyetizolam; EZ-M3-G1, EZ-M3-glucuronide 1; EZ-M3-G2, EZ-M3-glucuronide 2; EZ-M6-G, EZ-M6-glucuronide. 
の面積值 $+\mathrm{EZ}-\mathrm{M} 3-\mathrm{G} 2$ の面積値 $)]$

- $[\mathrm{EZ}-\mathrm{M} 6-\mathrm{G}$ の濃度 $]=[\mathrm{EZ}-\mathrm{M} 6$ の濃度増加分 $] \times$ [EZ-M6-G の分子量 (534)/EZ-M6の分子量 (358)]

さらに, 各被験者について, 算出した濃度および 各プロトン化分子の面積值に基づき，比例計算によ り他の試料の抱合体濃度についても算出した（Table 4).

その結果，3種の抱合体が，分析を実施した摄取 後50時間弱女でのすべての試料で検出され，その濃 度はいずれも $1 \mathrm{ng} / \mathrm{mL}$ 以上であった。 また，摂取 後約50時間までの, 㨟取量 (EZ $1 \mathrm{mg})$ に対する各 成分の累積排泄量の割合（モル換算，摂取後48ある いは49時間までの累積）は, EZ-M3-G1 が4.0-6.1 \%, EZ-M3-G2 が3.1-4.1\%（EZ-M3-G1 および EZ-M3-G2 の合計は8.1-9.2\%), EZ-M6-G が9.4$14 \%$ であった。ささらに，摂取量に対する総 EZ-M3 (EZ-M3 + EZ-M3-G1 + EZ-M3-G2) および総 EZM6（EZ-M6+EZ-M6-G）は，それぞれ18-22\%お よび9.5-14\%であったことから（Table 3 および Table 4)，尿中に最も多く排泄される代謝物は EZM3 であることが示された. 一方, グルクロン酸抱 合体のなかでは，EZ-M6-G が最も多く排泄される ことが示され，EZ-M6 は $98 \%$ 以上がグルクロン酸 抱合体として排泄されることが明らかとなった (Table 5)。一方，EZ-M3 は，摂取後48時間あるい は49時間までの累計で算出すると，概ね $50 \%$ がグル クロン酸抱合体として排泄されることが示された。

また，各グルクロン酸抱合体の濃度推移に着目す ると，以下の傾向が観察された。 その典型的な一例 (Subject 2) をFig. 4 に示す.グルクロン酸抱合体 のなかで最も高濃度を示したのは EZ-M6-Gで, 摂取後 12 時間までに $200 \mathrm{ng} / \mathrm{mL}$ 以上に達してお り，摂取後初期（15-16時間まで）においては，EZM3-G1 および EZ-M3-G2 と比べて数倍の濃度で 検出されている。一方, それ以降, 特に摂取後24時 間以降に打いて，EZ-M6-G は，EZ-M3-G1 抢よ び EZ-M3-G2 と同程度, あるいはそれらよりも低 い濃度で検出される傾向にあった。これは, EZ$\mathrm{M} 3$ のグルクロン酸抱合体の方が, EZ-M6-Gより も尿中濃度の減少が緩やかであることを示すもので
Table 5 Ratios of the amounts of metabolites excreted in urine to dose after a single ingestion EZ.

\begin{tabular}{|c|c|c|c|c|}
\hline Subject 1 & \multicolumn{2}{|c|}{ Total EZ-M3 } & \multicolumn{2}{|c|}{ Total EZ-M6 } \\
\hline $\begin{array}{l}\text { Collection } \\
\text { interval } \\
(\mathrm{h})\end{array}$ & $\begin{array}{c}\text { Ratio of } \\
\text { detected } \\
\text { amounts to } \\
\text { dose }(\%)\end{array}$ & & $\begin{array}{c}\text { Ratio of } \\
\text { detected } \\
\text { amounts to } \\
\text { dose }(\%)\end{array}$ & \\
\hline $0-12$ & 5.6 & {$[58]$} & 6.4 & {$[99]$} \\
\hline $12-24$ & 5.8 & {$[47]$} & 2.3 & {$[99]$} \\
\hline $24-34$ & 3.4 & {$[47]$} & 0.57 & {$[98]$} \\
\hline $34-49$ & 3.8 & {$[42]$} & 0.34 & {$[98]$} \\
\hline Total & 19 & [49] & 10 & {$[99]$} \\
\hline Subject 2 & Total EZ & M3 & Total EZ & M6 \\
\hline $\begin{array}{l}\text { Collection } \\
\text { interval } \\
(\mathrm{h})\end{array}$ & $\begin{array}{c}\text { Ratio of } \\
\text { detected } \\
\text { amounts to } \\
\text { dose }(\%)\end{array}$ & & $\begin{array}{l}\text { Ratio of } \\
\text { detected } \\
\text { amounts to } \\
\text { dose }(\%)\end{array}$ & \\
\hline $0-11$ & 5.0 & {$[53]$} & 7.2 & {$[99]$} \\
\hline $11-24$ & 6.4 & {$[53]$} & 3.6 & {$[99]$} \\
\hline $24-36$ & 3.2 & {$[57]$} & 0.89 & {$[99]$} \\
\hline $36-48$ & 2.6 & {$[43]$} & 0.38 & {$[99]$} \\
\hline Total & 17 & {$[52]$} & 12 & {$[99]$} \\
\hline Subject 3 & Total E & M3 & Total $\mathrm{F}$ & M6 \\
\hline $\begin{array}{l}\text { Collection } \\
\text { interval } \\
(\mathrm{h})\end{array}$ & $\begin{array}{l}\text { Ratio of } \\
\text { detected } \\
\text { amounts to } \\
\text { dose }(\%)\end{array}$ & & $\begin{array}{l}\text { Ratio of } \\
\text { detected } \\
\text { amounts to } \\
\text { dose }(\%)\end{array}$ & \\
\hline $0-11$ & 4.7 & {$[60]$} & 7.9 & {$[99]$} \\
\hline $11-24$ & 5.6 & {$[52]$} & 4.7 & [99] \\
\hline $24-36$ & 4.0 & {$[42]$} & 1.5 & {$[99]$} \\
\hline $36-48$ & 2.0 & {$[40]$} & 0.40 & [99] \\
\hline Total & 16 & {$[50]$} & 14 & [99] \\
\hline
\end{tabular}

EZ, etizolam; EZ-M3, 8- $\alpha$-hydroxyetizolam; EZM6, 1-hydroxyetizolam.

The numbers in parentheses indicate the ratios (\%) of glucuronides to total EZ-M3 or total EZ-M6.

ある.さらに，EZ-M3-G1 および EZ-M3-G2 を比 較すると, 摂取後初期（7-8 時間）では EZ-M3G2 の方が高濃度であったのに対し, 摂取後24時間 以降はいずれの被験者に拈いても EZ-M3-G1 の方 が高濃度に転じた。従って, EZ 摂取後, より長期 間にわたって検出される抱合体は EZ-M3-G1 であ り，各グルクロン酸抱合体の濃度比によって $\mathrm{EZ}$ 摂 


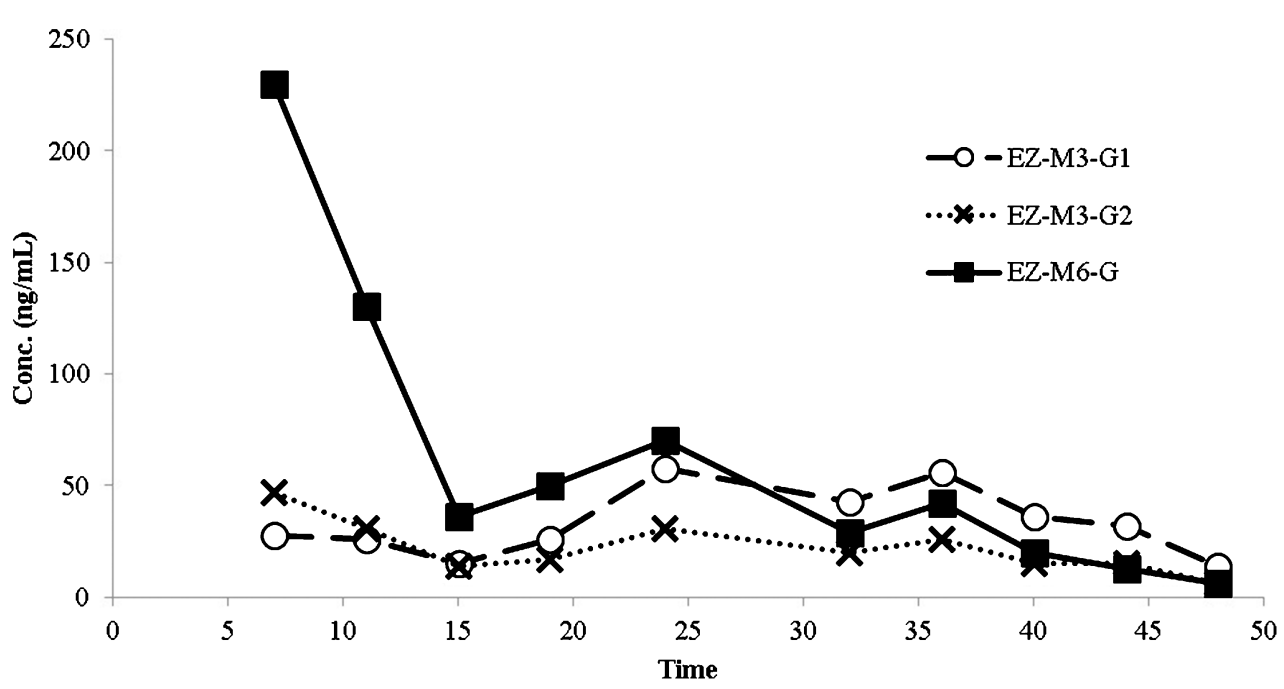

Fig. 4 Urine excretion profile of glucuronides of EZ-M3 and EZ-M6 (subject 2).

EZ, etizolam; EZ-M3, 8- $\alpha$-hydroxyetizolam; EZ-M6, 1-hydroxyetizolam; EZ-M3-G1, EZ-M3glucuronide 1; EZ-M3-G2, EZ-M3-glucuronide 2; EZ-M6-G, EZ-M6-glucuronide.

取からの経過時間を推定できる可能性が示唆され る.

\section{$3.3 \mathrm{EZ}$ 摂取を証明するための分析}

本研究の結果から，EZの代謝物は比較的高い割 合でグルクロン酸抱合体として排泄されることが明 らかとなった。しかしながら，法科学分野における 薬物鑑定において，成分の同定を行うためには基本 的に標準物質が必要とされる. 本研究で対象とした グルクロン酸抱合体（EZ-M3-G1，EZ-M3-G2 お よび EZ-M6-G）は現状で標準物質の入手が困難で あるため, EZの拱取証明では，酵素加水分解を 行った後 EZ，EZ-M3 抢よび EZ-M6 をターゲット に分析を進めることが推奨される。

本研究で明らかになった尿中排泄プロファイルか ら考察すると, 酵素加水分解を行うことで摂取後初 期には EZ-M6が最も高濃度で検出されると共に未 変化体 $\mathrm{EZ}$ および $\mathrm{EZ}-\mathrm{M} 3$ が併せて検出される. 摂 取後50時間以降になると, EZ および EZ-M6 は不 検出あるいは検出限界付近になるため, EZ-M3 ターゲットとして分析することが適切であると考え られる。な拈, 本研究の分析条件（検出限界：0.05 $\mathrm{ng} / \mathrm{mL}$ ) では, EZ-M3 を遊離体として摂取後約 1 週間検出することが可能であり, さらに酵素加水分 解により検出期間の延長が期待できる. しかしなが
ら, 酵素加水分解を行っても EZ-M3 の増加は約 2 倍に留まり大幅な検出期間の延長は望めないため, 性犯罪事案などの被害から 1 週間以上申告が遅れた 場合には，尿よりも検出可能期間の長い毛髪鑑定を 視野に入れて検討する必要があると考えられる.

また，法科学分野では犯罪事実などの立証のた め, 鑑定結果を基に薬物の摂取時期について見解を 求められることがある.そのようなケースでは, EZ と共に 5 種類の代謝物をそれぞれ分析し，それ らの濃度と共に各成分の濃度比を比較検討すること で，摂取してからの概ねの経過日時を推定すること も可能と考えられる.

\section{結 語}

EZ は, 国内で流通量の多い処方箋医薬品の $1 つ$ であり，その催眠作用から犯罪に悪用されることが 多く，実際の鑑定でも検出例の多い薬物である，本 研究では, 性犯罪などで想定される単回拱取の条件 下で，第二相代謝物（グルクロン酸抱合体）を初め て検出すると共に，それらを含む主要代謝物の尿中 排泄プロファイルを明らかにした。 その結果，未変 化体 EZ が尿中に排泄される割合は投与量の $0.3 \%$ 未満であったのに対し，主代謝物である EZ-M3 お よび EZ-M6 が排泄される割合は，グルクロン酸抱 
合体を含めると，それぞれ投与量の概ね10〜20\%で あることが示された。従って, EZ摂取の指標とし ては，主代謝物である EZ-M3 打よび EZ-M6を ターゲットとすることが適切であると考えられ，特 に EZ-M3 は尿中濃度の減少が緩やかであり, 摂取 後約 1 週間まで検出が可能であることが示唆された （検出限界：0.05 ng/mL)。 また， EZ-M3 抢よび EZ-M6 がグルクロン酸抱合体として尿排泄される 割合は，それぞれ約50\%および98\%以上であること が示され，酵素加水分解による各遊離体の増加幅は 約 2 倍抢よび50倍以上と見込まれるため，加水分解 処理による検出可能期間の若干の延長も期待でき る. 本研究のデータは，第二相代謝物を含む主要代 謝物の尿中排泄プロファイルを示したものであり， EZ の摂取証明を行う上で有用な知見になるものと 考えられる.

\section{利益相反}

本研究について, 申告すべき利益相反関連事項は ない。

\section{引用文献}

1) World Health Organization, WHO Expert Committee on Drug Dependence - Twenty-sixth Report/WHO Technical Report Series 787, pp. 10-11, 1989.

2) World Health Organization, $42^{\text {nd }}$ Expert Committee on Drug Dependence Critical Review Report: Etizolam, 2019, available from [https:// www.who.int / medicines / access / controlledsubstances/Final_Etizolam.pdf?ua $=1]$, accessed Oct 23, 2020.

3）松本俊彦，処方薬乱用・依存からみた今日の 精神科薬物治療の課題：ベンゾジアゼピンを中 心に，臨床精神薬理，16, 803-812, 2013.

4）松本俊彦, 嶋根卓也, 尾崎 茂, 乱用 ·依存 の危険性の高いベンゾジアゼピン系薬剤同定の 試み：文献的対照群を用いた乱用者選択率と医 療機関処方率に関する予備的研究, 精神医学,

54, 201-209, 2012.

5）厚生労働省，新たに 3 物質を向精神薬に指 定，available from [https://www.mhlw.go.jp/ seisakunitsuite/bunya/kenkou_iryou/iyakuhin / yakubuturanyou/oshirase/20160914-1.html], accessed Oct 23, 2020.

6) Salamone SJ, Honasoge S, Brenner C, McNally AJ, Passarelli J, Goc-Szkutnicka K, Brenneisen R, elSohly MA and Feng S, Flunitrazepam Excretion Patterns using the Abuscreen OnTrak and OnLine Immunoassays: Comparison with GCMS. J. Anal. Toxicol., 21, 341-345, 1997.

7) Negrusz A, Moore CM, Stockham TL, Poiser KR, Kern JL, Palaparthy R, Le NL, Janicak PG and Levy NA, Elimination of 7-aminoflunitrazepam and flunitrazepam in urine after a single dose of Rohypnol(R. J. Forensic Sci., 45, 1031-1040, 2000.

8) Snyder H, Schwenzer KS, Pearlman R, McNally AJ, Tsilimidos M, Salamone SJ, Brenneisen R, ElSohly MA and Feng S, Serum and urine concentrations of flunitrazepam and metabolites, after a single oral dose, by immunoassay and GC-MS. $J$. Anal. Toxicol., 25, 699-704, 2001.

9) Forsman M, Nystrom I, Roman M, Berglund L, Ahlner $\mathrm{J}$ and Kronstrand R, Urinary detection times and excretion patterns of flunitrazepam and its metabolites after a single oral dose. J. Anal. Toxicol., 33, 491-501, 2009.

10) Tsujikawa $\mathrm{K}$, Kuwayama $\mathrm{K}$, Miyaguchi $\mathrm{H}$, Kanamori T, Iwata $\mathrm{Y}$, Inoue $\mathrm{H}$ and Kishi T, Urinary excretion profiles of two major triazolam metabolites, alpha-hydroxytriazolam and 4hydroxytriazolam. J. Anal. Toxicol., 29, 240-243, 2005.

11) Kato $Y$ and Nishimine $H$, Absorption, distribution and excretion of a new thienodiazepine derivative $(\mathrm{Y}-7131)$ in rats and mice. Arz. Forsch., 28, 1170-1173, 1978.

12) Nakamae $T$, Shinozuka $T$, Sasaki $C$, Ogamo A, Murakami-Hashimoto C, Irie W, Terada M, Nakamura S, Furukawa M and Kurihara K., Case report: Etizolam and its major metabolites in two 
unnatural death cases. Forensic Sci. Int., 182, 16, 2008.

13) Namera A, Makita R and Nagao M, Comparison of four immunoassay screening devices for detection of benzodiazepine and its metabolites in urine: mainly detection of etizolam, thienodiazepine and its metabolites. Jpn. J. Toxicol., 24, 2734, 2011.

14) Miki A, Tatsuno $M$, Katagi $M$, Nishikawa $M$ and Tsuchihashi $\mathrm{H}$, Simultaneous Determination of Eleven Benzodiazepine Hypnotics and Eleven
Relevant Metabolites in Urine by Column-Switching Liquid Chromatography-Mass Spectrometry. J. Anal. Toxicol., 26, 87-93, 2002.

15) Drummer OH, Rago MD and Gerostamoulos $\mathrm{D}$, Analysis of benzodiazepines for drug-facilitated assaults and abuse settings (urine). LC-MS in Drug Analysis, 23-39, 2019.

16) Fracasso C, Confalonieri S, Garattini $S$ and Caccia S., Single and multiple dose pharmacokinetics of etizolam in healthy subjects. Eur. J. Clin. Pharmacol., 40, 181-185, 1991. 